\title{
Borderline Ovarian Clear Cell Tumor/Atypical Proliferative Ovarian Clear Cell Tumor with Intraepithelial Carcinoma
}

National Cancer Institute

\section{Source}

National Cancer Institute. Borderline Ovarian Clear Cell Tumor/Atypical Proliferative

Ovarian Clear Cell Tumor with Intraepithelial Carcinoma. NCI Thesaurus. Code C40082.

A non-invasive clear cell adenofibromatous neoplasm that arises from the ovary. It is characterized by the presence of atypical neoplastic clear or hobnail epithelial cells and intraepithelial carcinoma. 